DOI: https://doi.org/10.24127/ajpm.v10i4.4033

\title{
TEORI BEBAN KOGNITIF: PETA KOGNITIF DALAM PEMECAHAN MASALAH PADA MATEMATIKA SEKOLAH
}

\author{
Barep Yohanes ${ }^{1}$, Feby Indriana Yusuf ${ }^{2^{*}}$ \\ 1,2* Universitas PGRI Banyuwangi, Banyuwangi, Indonesia \\ ${ }^{*}$ Corresponding author. \\ E-mail: $\quad \frac{\text { barepyohanes@gmail.com }}{{ }^{1)}}{ }^{\text {feby.statistika@gmail.com }}{ }^{2}$
}

Received 22 July 2021; Received in revised form 13 September 2021; Accepted 15 December 2021

\begin{abstract}
Abstrak
Penelitian ini merupakan penelitian kualitatif deskriptif yang bertujuan untuk mendeskripsikan Peta Kognitif dalam pemecahan masalah berdasarkan teori beban kognitif. Penelitian dilakukan dengan tes untuk melihat peta kognitif dari peserta didik. Peta kognitif didasarkan pada pengetahuan, masalah, prosedur, dan konsep. Hasil penelitian menunjukkan bahwa dalam peta kognitif mahasiswa dalam pemecahan masalah dapat terlihat adanya beban kognitif yang muncul. Peta kognitif yang interkoneksi antara pengetahuan, masalah, prosedur, dan konsep memiliki beban kognitif baik itu beban kognitif intrinsic maupun germane. Kesimpulan pada penelitian ini bahwa peta kognitif dalam penyelesaian masalah terdapat beban kognitif yang muncul dalam perkuliahan Matematika Sekolah 1. Beban kognitif muncul dalam setiap interkoneksi pengetahuan, masalah, prosedur, dan konsep.
\end{abstract}

Kata kunci: Beban kognitif; cognitive map; matematika sekolah; problem solving.

\begin{abstract}
This research is a descriptive qualitative research that aims to describe the Cognitive Map in problem solving based on cognitive load theory. The research was conducted with a test to see the cognitive map of the students. Cognitive maps are based on knowledge, problems, procedures, and concepts. The results showed that the cognitive map of students in problem solving can be seen that there is a cognitive load that appears. Cognitive maps that interconnect knowledge, problems, procedures, and concepts have a cognitive load, both intrinsic and germane. The conclusion of this study is that there is a cognitive load in problem solving that appears in School Mathematics lectures 1. Cognitive load appears in every interconnection of knowledge, problems, procedures, and concepts.
\end{abstract}

Keywords: Cognitive load; cognitive map; problem solving ; school mathematics.

This is an open access article under the Creative Commons Attribution 4.0 International License

\section{PENDAHULUAN}

Pembelajaran merupakan usaha untuk mewujudkan situasi belajar yang melibatkan interaksi antara pendidik, peserta didik, dan sumber belajar (Lampiran Permendikbud No 103 Tahun 2014, 2014). Pembelajaran memberikan kesempatan kepada peserta didik untuk dapat belajar sesuai dengan kemampuan yang dimiliki. Perlu ada upaya terus menurus untuk memperbaiki kualitas pendidikan (Kaune et al.,
2011; Voutsina \& Ismail, 2011). Pembelajaran yang baik harus bisa memfasilitasi peserta didik untuk aktif, terlibat dalam proses, memiliki pengalaman, bekerja sama dalam kelompok, dan bekerja dengan konsep diri (Choppin, 2011; Gifford \& Rockliffe, 2012; Murray, 2011; Smith, 2010).

Kognitif merupakan bagian dari teori belajar yang berkembang untuk mengetahui proses seseorang dalam 
mengelola pengetahuan. Teori beban kognitif merupakan bagian dari teori pembelajaran yang berupaya untuk memperbaiki pembelajaran (Kalyuga, 2011; Sweller et al., 2019). Peta kognitif merupakan gambaran dan konsep mental yang dibangun untuk memvisualisasi dan mengasimilasi informasi (Sammut-Bonnici \& McGee, 2015). Peta kognitif dapat memberikan gambaran kemampuan seseorang dalam membangun pengetahuan yang dapat digunakan untuk memperbaiki pembelajaran melalui analisis beban kognitif.

Beban Kognitif sangat penting karena berhubungan dengan memori kerja saat memproses suatu informasi (Plass et al., 2010; Sweller et al., 2011). Sedangkan peta kognitif menggambarkan terbentuknya pengetahuan yang dipelajari sehingga membentuk suatu skema yang utuh pada seseorang (Bottini \& Doeller, 2020).

Banyak penelitian tentang beban kognitif dan peta kognitif dalam lingkup proses belajar. Pembelajaran harus semaksimal mungkin untuk dapat mengelola Beban Kognitif Intrinsic, menekan serendah mungkin Beban Kognitif Extraneous, dan meningkatkan Beban Kognitif Germane (de Jong, 2010; Lin \& Lin, 2014). Beban kognitif dalam pembelajaran matematika sekolah selalu muncul dengan ketiga jenis beban kognitif tersebut (Yohanes et al., 2016). Banyak peneliti berupaya mengukur beban kognitif dalam pembelajaran guna untuk memberikan terobosan dalam kegiatan pembelajaran (Skulmowski \& Rey, 2017). Terdapat beberapa hal yang mempengaruhi beban kognitif dalam kegiatan belajar seperti, animasi, e-learning, keragaman pembelajaran, dan video ceramah (Costley et al., 2020; Costley \& Lange, 2017; Lange \& Costley, 2018; Pink \& Newton, 2020).
Peta kognitif dimiliki oleh seseorang sejak dalam kandungan yang dapat dilihat dari sistem sensorimotor (Ahmed et al., 2020). Dari hasil penelitian, dapat dibedakan dua jenis proses mental yang digunakan untuk membangun Cognitive Map. Pemikiran sistem 1 yaitu cepat, intuitif, naluriah, dan otomatis, sedangkan Pemikiran Sistem 2 yaitu berpikir lambat, sadar, analitis, dan disengaja (SammutBonnici \& McGee, 2015). Peta Kognitif menggambarkan interkoneksi antara pengetahuan, masalah, prosedur dan konsep dari hasil berpikir seseorang (Subanji, 2015).

Pemecahan Masalah merupakan salah satu dari 5 standar proses yang harus terpenuhi dalam pembelajaran Matematika Sekolah (NCTM, 2000). Pemecahan masalah merupakan proses pembelajaran matematika yang melibatkan meta-kognitif (Muis et al., 2015; Tachie, 2019). Pemecahan masalah dipengaruhi oleh pengetahuan sebelumnya yang telah dimiliki oleh peserta didik (Santos-Trigo, 2014). Pemecahan Masalah dapat dilakukan dengan menggunakan langkah-langkah yang telah dikemukakan oleh Polya (Putu et al., 2021; Yayuk \& Husamah, 2020).

Masalah dalam pembelajaran matematika bukanlah suatu hal yang asing. Masalah dapat memberikan stimulus pada peserta didik untuk berproses dalam membangun pengetahuan. Masalah tidaklah sama dengan suatu kegiatan atau contoh soal yang rutin. Hasil kerja peserta didik dalam menyelesaikan masalah sebagian besar dalam pengamatan sangatlah sedikit yang mengarah pada hasil akhir yang diharapkan. Terkadang tidak ada yang benar dalam tujuan yang diinginkan pada masalah yang diberikan meskipun proses pengerjaannya terlihat sangat panjang. 
DOI: https://doi.org/10.24127/ajpm.v10i4.4033

Permasalahan dari peserta didik dalam menyelesaikan masalah matematika tersebut haruslah diketahui peta kognitif dari peserta didik. Hasil peta kognitif tersebut dapat diketahui arah skema pengetahuan dari peserta didik sehingga perlunya penambahan pengetahuan dan perbaikan pembelajaran.
Pemecahan masalah akan memberikan Beban bagi Kognitif peserta didik dan juga akan memberikan suatu alur konsep pemecahan masalah yang dinamakan Peta Kognitif. Hubungan beban kognitif dan peta kognitif dapat dilihat pada Gambar 1.

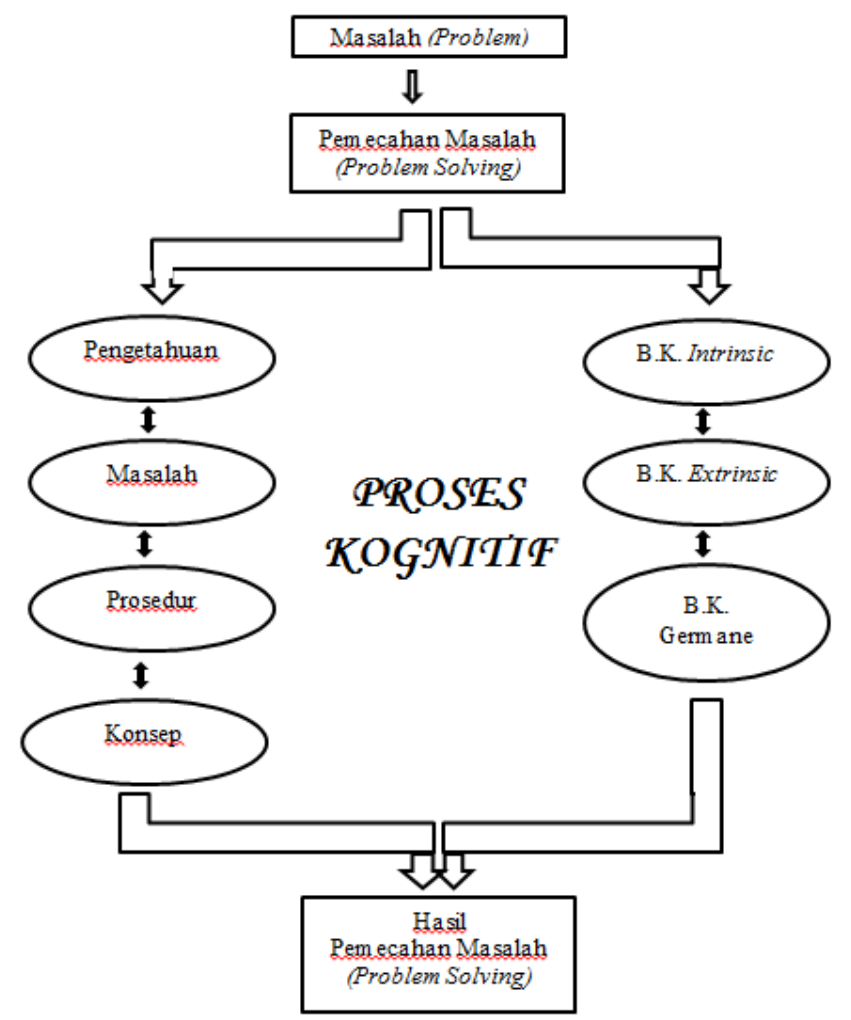

Gambar 1. Hubungan beban kognitif, peta kognitif, dan pemecahan masalah

Dari latar belakang diatas maka tujuan dari penelitian ini adalah untuk mendeskripsikan peta kognitif dalam penyelesaian masalah berdasarkan teori beban kognitif.

\section{METODE PENELITIAN}

Penelitian ini merupakan penelitian kualitatif deskriptif. Penelitian dilakukan dengan menggunakan metode penelitian yang dikemukakan oleh (Creswell, 2014). dengan 5 langkah yaitu: (1) Persiapan; (2) Prasurvei; (3) Pengambilan Data; (4) Pengelolahan Data; (5) Penulisan Laporan.

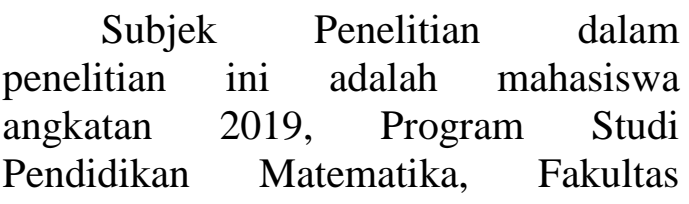
MIPA, Universitas PGRI Banyuwangi Semester Genap tahun pembelajaran 2019/2020. Penelitian dilakukan di Universitas PGRI Banyuwangi dengan Jumlah mahasiswa yang dijadikan objek penelitian ini adalah 7 mahasiswa.

Instrumen penelitian yang digunakan pada penelitian ini adalah tes untuk melihat peta kognitif mahasiswa. Teknik analisis data menggunakan 8 langkah, yaitu: Mentranskrip data 
verbal, Memahami data yang telah diperoleh, Reduksi data, Pengkodingan data, menggambarkan struktur dari pengkodingan, Analisis, Analisis halhal yang menarik, dan Penarikan kesimpulan. Teknik pengecekan keabsahan temuan menggunakan Teknik triangulasi data. Masalah yang diberikan berupa soal yang ditunjukkan pada Gambar 2. Kemunculan Beban Kognitif pada empat unsur interkoneksi peta kognitif memberikan gambaran tentang kemampuan prasyarat sampai hasil akhir yang diperoleh dalam pemecahan masalah.

\section{Pecahkanlah masalah di bawah ini menggunakan strategi yang paling sesuai. Sebutkan} strategi apa yang Anda gunakan dalam memecahkan masalah di bawah ini

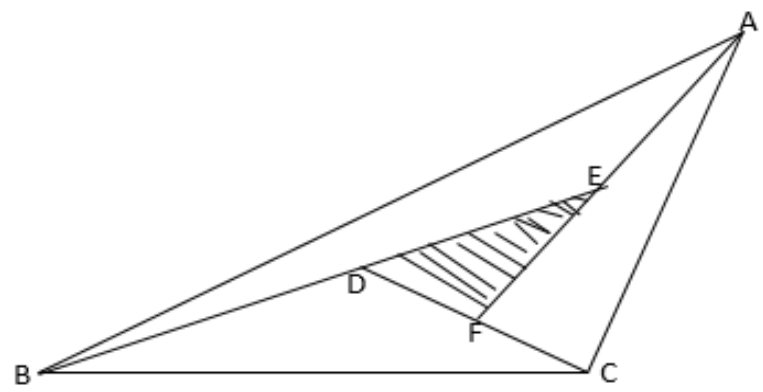

Tentukan luas daerah yang tidak diarsir pada gambar disamping apabila luas segitiga DEF adalah $100 \mathrm{~cm}^{2}$, dan D merupakan titik tengah ruas garis $\mathrm{BE}, \mathrm{F}$ merupakan titik tengan ruas garis $\mathrm{CD}$, serta E merupakan titik tengah ruas garis $\mathrm{AF}$.

Gambar 2. Masalah dalam pembelajaran matematika sekolah

Beban Kognitif dapat dilihat dari indikator munculnya Beban Kognitif pada Gambar 3 berdasarkan hasil pembahasan dan penelitian (Kalyuga, 2011; Plass et al., 2010; Sweller et al., 2019).

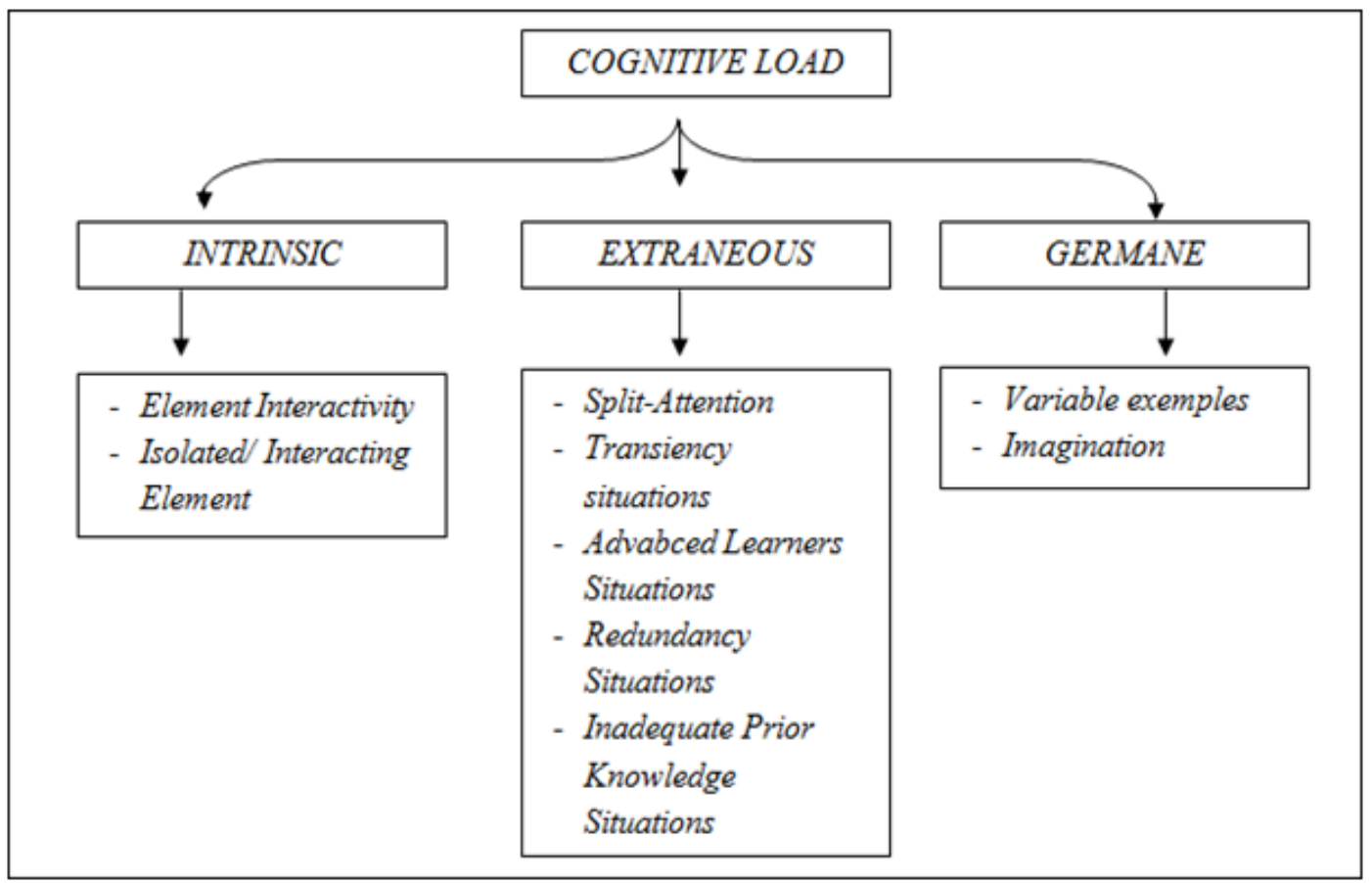

Gambar 3. Penyebab munculnya beban kognitif 
DOI: https://doi.org/10.24127/ajpm.v10i4.4033

\section{HASIL DAN PEMBAHASAN}

Penelitian ini dilakukan dengan memberikan tes kepada mahasiswa untuk mengetahui langkah-langkah mahasiswa dalam memecahkan masalah. Tes yang diberikan merupakan tes pemecahan masalah yang telah disusun berdasarkan kemampuan dari mahasiswa dalam belajar Matematika Sekolah. Tes yang diberikan dapat dilihat pada gambar 2. Analisis data dijabarkan berdasarkan 4 komponen Peta Kognitif yang Interkoneksi yaitu,: (1) Pengetahuan; (2) Masalah; (3) Prosedur; dan (4) Konsep.

\section{Pengetahuan}

Pengetahuan merupakan modal awal dalam melakukan pemecahan masalah. Beban Kognitif Intrinsic sangat dipengaruhi oleh pengetahuan prasyarat dari peserta didik (Huang, 2018). Pengetahuan yang dimiliki peserta didik pada saat mendapatkan masalah yang diberikan ternyata memiliki 2 golongan.

Golongan yang pertama bahwa peserta didik memiliki pengetahuan atau lebih menonjolkan langkah-langkah dalam menyelesaikan masalah, bukan penyelesaian masalahnya. Terlihat bahwa 4 peserta didik menyebutkan langkah untuk menyelesaikan masalah seperti pada Gambar 4. Beban kognitif Intrinsic berhubungan dengan elemen interaktivitas dari proses suatu pemecahan masalah.

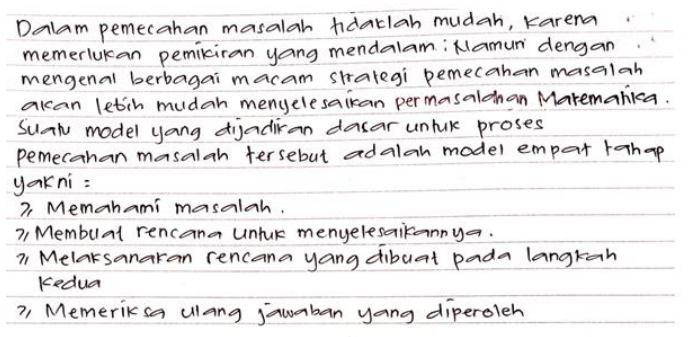

Gambar 4. Hasil kerja mahasiswa
Golongan yang kedua bahwa peserta didik memiliki pengetahuan atau menonjolkan pemahaman tentang penyelesaian dari masalah tersebut. Terlihat bahwa 2 peserta didik memberikan gambaran tentang analisis matematika dari pemecahan masalah seperti pada gambar 5. Peserta didik lebih menekankan hasil dari pertanyaan yang dimaksudkan pada masalah tersebut. Peserta didik menghubungkan masalah tersebut dengan konsep segitiga

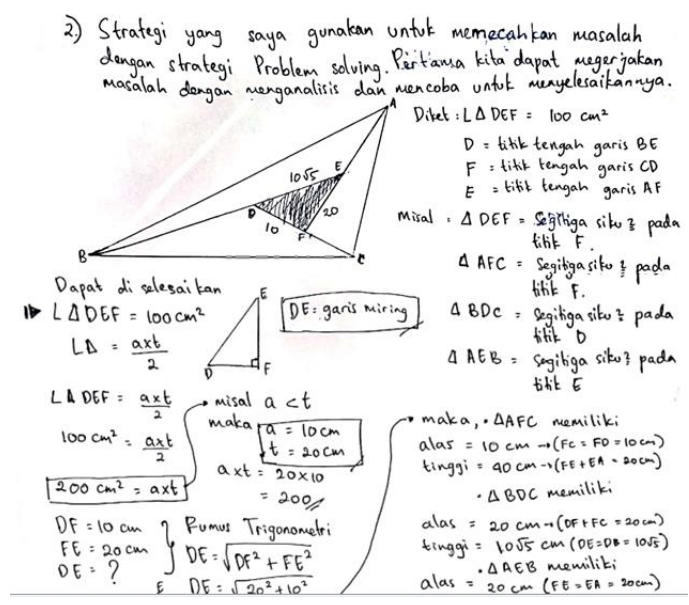

Gambar 5. Hasil kerja mahasiswa

Hasil tersebut sejalan dengan hasil pembahasan dari Huang (2018) bahwa pengetahuan prasyarat mempengaruhi beban kognitif. Elemen Interaktivitas terbentuk dari pengetahuan tentang langkah penyelesaian masalah dan yang lain dari konsep matematika. Kedua elemen interaktivitas ini merupakan beban kognitif Intrinsic yang mengisi peta kognitif dari tahapan pengetahuan pada penyelesaian masalah.

Hasil penelitian ini dapat diketahui bahwa pengetahuan prasyarat peserta didik masih sangat kurang. Peserta didik harus lebih lagi belajar akan materi-materi prasyarat yang dibutuhkan. 
DOI: https://doi.org/10.24127/ajpm.v10i4.4033

\section{Masalah}

Masalah yang telah diberikan merupakan soal dari suatu bangun bidang dua dengan bagian yang diarsir dan yang tidak diarsir seperti pada gambar 2. Masalah yang diberikan merupakan penyebab munculnya beban Kognitif Germane yaitu Variable Exemple (Sweller et al., 2019).

Masalah yang diberikan dengan jelas terdapat dua poin dari pertanyaan permasalahan tersebut. Kedua poin tersebut memberikan interaksi terhadap elemen-elemen yang berhubungan untuk membangun suatu penyelesaiaan dari permasalahan yang diberikan.

Pertama, Sebutkan Strategi apa yang saudara gunakan dalam pemecahan masalah dibawah ini?. Elemen yang berinteraksi dalam penyelesaiaan masalah tersebut terletak pada stategi-strategi yang digunakan dalam pemecahan masalah. Adapun strategi pemechan masalah ada 12 strategi yang telah dikemukakan oleh Loren C seperti pada Gambar 6 yang disampaikan pada saat perkuliahan.

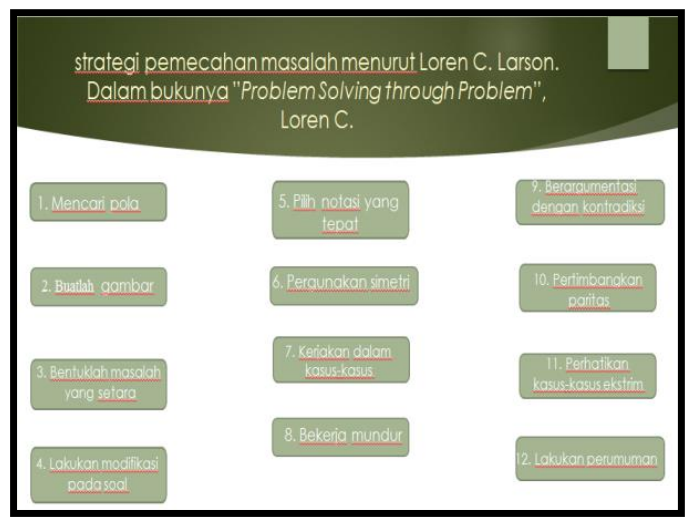

Gambar 6. Strategi pemecahan masalah

Terdapat 6 peserta didik yang memberikan strategi menurut mereka tepat untuk menyelesaikan masalah tersebut. Peserta didik hanya memberikan uraian tentang strateginya. Peserta didik tidak menjabarkan suatu langkah demi langkah pada strategi tersebut untuk mendapatkan hasil penyelesaian yang diinginkan.

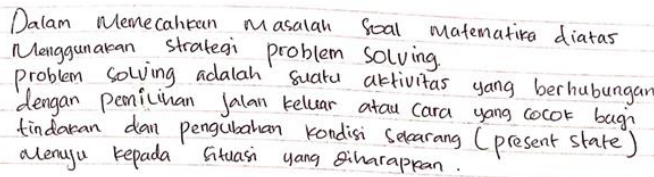

Gambar 7. Hasil Kerja Mahasiswa

$$
\text { Kedua ditanyakan bahwa }
$$
Tentukan luas daerah yang tidak diarsir?. Terdapat 2 peserta didik memberikan penjabaran tentang luas pada suatu bidang dengan menghubungkan pada konsep segitiga seperti pada Gambar 8. Ada suatu elemen interaktivitas antara luas bangun yang diarsir dengan konsep segitiga.

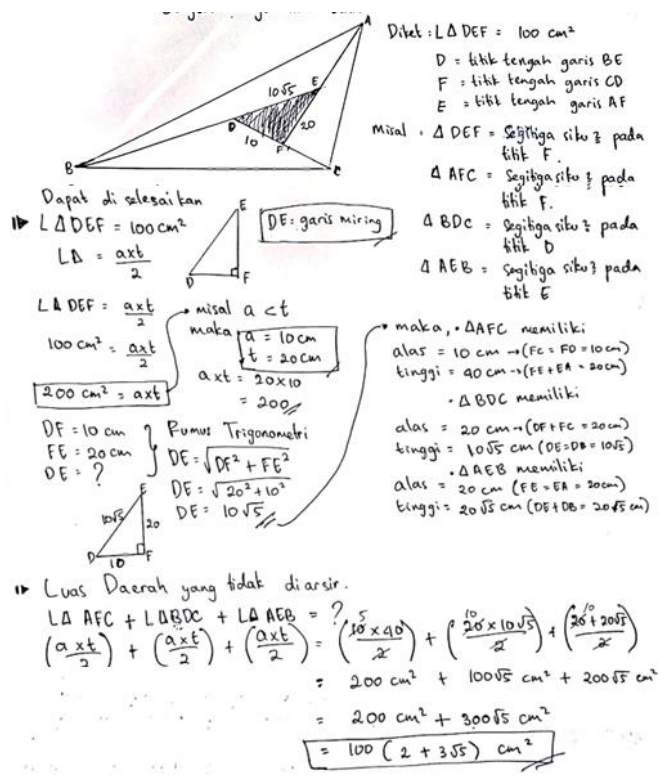

Gambar 8. Hasil Kerja Mahasiswa

Sesuai dengan penelitian bahwa pemecahan masalah melibatkan metakognitif (Muis et al., 2015; Tachie, 2019). Meta kognitif memberikan beban kognitif pada peserta didik saat mereka mendapatkan masalah matematika.

Hasil ini menunjukkan bahwa adanya miskonsepsi dalam pemahaman masalah yang diberikan. Beban kognitif 
membebani peserta didik dalam menyelesaikan masalah. Peserta didik perlu adanya bimbingan dalam memahami masalah sehingga tidak ada miskonsepsi dalam pemecahan masalah.

\section{Prosedur}

Prosedur pemecahan masalah merupakan salah satu konstruksi dari beban yang ditempatkan pada memori kerja (Ginns \& Leppink, 2019). Perilaku belajar akan membuat peserta didik untuk menginvestasikan sumberdaya kognitif dan metakognitifnya dalam menyelesaikan masalah. Kemampuan pengaturan diri (Selfregulation in Learning) dalam penyelesaian masalah tersebut menyebabkan beban kognitif (Seufert, 2018)

Seluruh peserta didik menuangkan ide mereka dalam upaya menyelesaikan masalah yang diberikan. Prosedur tersebut dapat terlihat dari gambar 4, gambar 5, gambar 7, dan gambar 8 . Prosedur yang dituangkan merupakan hasil pengetahuan dan pemahaman masalah yang akhirnya menghasilkan suatu prosedur.

Sesuai dengan penelitian bahwa prosedur yang tertuang pada hasil kerja peserta didik menggambarkan adanya materi prasyarat yang dimiliki. Minat yang dituangkan dalam hasil kerja memberikan nilai atau beban pada kognitif peserta didik (Friedman et al., 2019).

Hasil ini menunjukkan bahwa prosedur memberikan beban kognitif yang sangat mempengaruhi dalam proses belajar peserta didik. Prosedur yang baik akan membawa pada suatu hasil yang baik. Prosedur yang baik juga harus diikuti oleh pengetahuan dan pemahaman masalah yang benar.

\section{Konsep}

Konsep merupakan penyusunan utama dalam pembentukan pengetahuan ilmiah dan filsafat pemikiran manusia. Konsep dalam penyelesaian masalah pada gambar 2 sangat erat hubungannya dengan konsep strategi penyelesaian masalah dan konsep segitiga.

Pemecahan masalah dalam pembelajaran daring ini memberikan kondisi yang sangat rumit dalam kebenaran konsep. Selaras dengan penelitian bahwa Kondisi dalam pembelajaran daring harus memungkinkan salah satu kondisi yaitu peserta didik harus secara mandiri mengupayakan kemampuan mereka untuk pemecahan masalah (Lange \& Costley, 2018). Kemampuan secara mandiri ini merupakan beban dalam kognitif peserta didik dalam pengaplikasian konsep pemecahan masalah.

\section{KESIMPULAN DAN SARAN}

Berdasarkan tujuan penelitian dapat ditarik suatu kesimpulan bahwa melalui peta kognitif dalam menyelesaikan masalah terdapat beban kognitif yang muncul dalam perkuliahan Matematika Sekolah 1. Beban kognitif muncul dalam setiap interkoneksi pengetahuan, masalah, prosedur, dan konsep.

Saran yang dapat diberikan untuk penelitian selanjutnya yaitu dapat dilakukan penelitian tentang pengukuran beban kognitif yang melibatkan peta kognitif, perlunya penelitian dalam pembelajaran tatap muka, dan pembahasan tentang kebenaran dari hasil pemecahan masalah.

\section{Ucapan Terimakasih}

Ucapan terimakasih yang sebesarbesarnya disampaikan kepada KEMENRISTEK/ BRIN LLDIKTI Wilayah VII yang telah membiayai 
penelitian ini. Dan juga menyampaikan ucapan terimakasih kepada segenap Civitas Universitas PGRI Banyuwangi dan juga LPPM UNIBA yang telah memberikan dukungan dalam terlaksananya penelitian.

\section{REFERENSI}

Lampiran Permendikbud no 103 tahun 2014, (2014).

Ahmed, E., El Khoribi, R. A., Darwish, G., Muzy, A., \& Bernot, G. (2020). Modeling of the development of the fetus cognitive map from the sensorimotor system. Egyptian Informatics Journal, 21(4), 191199.

https://doi.org/10.1016/j.eij.2020. 01.002

Bottini, R., \& Doeller, C. F. (2020). Knowledge Across Reference Frames: Cognitive Maps and Image Spaces. Trends in Cognitive Sciences, 24(8), 606619.

https://doi.org/10.1016/j.tics.2020. 05.008

Choppin, J. (2011). The role of local theories: Teacher knowledge and its impact on engaging students with challenging tasks. Mathematics Education Research Journal, 23(1), 5-25. https://doi.org/10.1007/s13394011-0001-8

Costley, J., Fanguy, M., Lange, C., \& Baldwin, M. (2020). The effects of video lecture viewing strategies on cognitive load. Journal of Computing in Higher Education, 0123456789.

https://doi.org/10.1007/s12528020-09254-y

Costley, J., \& Lange, C. (2017). The effects of lecture diversity on germane load. International Review of Research in Open and Distance Learning, 18(2), 27-46. https://doi.org/10.19173/irrodl.v1 $8 \mathrm{i} 2.2860$

Creswell, J. W. (2014). Research Design: Pendekatan Kualitatif, Kuantitatif, dan Mixed, edisi-3 (3rd ed.). Pustaka Pelajar.

de Jong, T. (2010). Cognitive Load Theory, Educational research, and instructional design: some food for thought. Instructional Science, $38(2)$, 105-134. https://doi.org/10.1007/s11251009-9110-0

Friedman, N., Fekete, T., Gal, K., \& Shriki, O. (2019). EEG-based prediction of cognitive load in intelligence tests. Frontiers in Human Neuroscience, 13(June). https://doi.org/10.3389/fnhum.201 9.00191

Gifford, S., \& Rockliffe, F. (2012). Mathematics difficulties: does one approach fit all? Research in Mathematics Education, 14(1), 115.

https://doi.org/10.1080/14794802. 2012.657436

Ginns, P., \& Leppink, J. (2019). Special Issue on Cognitive Load Theory: Editorial. Educational Psychology Review, 31(2), 255-259. https://doi.org/10.1007/s10648019-09474-4

Huang, Y. H. (2018). Influence of instructional design to manage intrinsic cognitive load on learning effectiveness. Eurasia Journal of Mathematics, Science and Technology Education, 14(6), 2653-2668. https://doi.org/10.29333/ejmste/90 264

Kalyuga, S. (2011). Informing: A cognitive load perspective. Informing Science: The International Journal of an Emerging Transdiscipline, 14(1), 
DOI: https://doi.org/10.24127/ajpm.v10i4.4033

33-45.

https://doi.org/10.28945/1349

Kaune, C., Cohors-Fresenborg, E., \& Nowinska, E. (2011). Development of metacognitive and discursive activities in Indonesian maths teaching a theory based design and test of a learning environment. Journal on Mathematics Education, 2(1), 1540.

https://doi.org/10.22342/jme.2.1.7 77.15-40

Lange, C., \& Costley, J. (2018). The moderating effects of intrinsic load on the relationship between self-regulated effort and germane load. Journal of Computer Assisted Learning, 34(6), 652660.

https://doi.org/10.1111/jcal.12269

Lin, J. J. H., \& Lin, S. S. J. (2014). Cognitive Load for Configuration Comprehension in ComputerSupported Geometry Problem Solving: an Eye Movement Perspective. International Journal of Science and Mathematics Education, 12(3), 605-627. https://doi.org/10.1007/s10763013-9479-8

Muis, K. R., Psaradellis, C., Lajoie, S. P., Di Leo, I., \& Chevrier, M. (2015). The role of epistemic emotions in mathematics problem solving.

Contemporary

Educational Psychology, 42, 172185.

https://doi.org/10.1016/j.cedpsych .2015.06.003

Murray, S. (2011). Declining participation in post-compulsory secondary school mathematics: Students' views of and solutions to the problem. Research in Mathematics Education, 13(3), 269-285. https://doi.org/10.1080/14794802. 2011.624731

NCTM. (2000). Principle and Standarts for School Mathematics. The National Council of Teachers of Mathematics, Inc.

Pink, A., \& Newton, P. M. (2020). Decorative animations impair recall and are a source of extraneous cognitive load. Advances in Physiology Education, 44(3), 376-382. https://doi.org/10.1152/ADVAN.0 0102.2019

Plass, J. L., Moreno, R., \& Brünken, R. (2010). COGNITIVE LOAD THEORY. Cambridge University Press.

Putu, N., Arilaksmi, G., \& Sulandra, I. M. (2021). Kemampuan Berpikir Kreatif Mahasiswa Pendidikan Matematika dalam Memecahkan Masalah Open-Ended Trigonometri. JIPM: Jurnal Ilmiah Pendidikan Matematika, 9(2), 1-13.

Sammut-Bonnici, T., \& McGee, J. (2015). Cognitive Map. Wiley Encyclopedia of Management, January, 1-3. https://doi.org/10.1002/97811187 85317.weom 120127

Santos-Trigo, M. (2014). Problem Solving in Mathematics Education. In Encyclopedia of Mathematics Education. https://doi.org/10.1007/978-94007-4978-8_129

Seufert, T. (2018). The interplay between self-regulation in learning and cognitive load. Educational Research Review, 24(August 2017), 116-129. https://doi.org/10.1016/j.edurev.2 018.03.004

Skulmowski, A., \& Rey, G. D. (2017). Measuring cognitive load in 
DOI: https://doi.org/10.24127/ajpm.v10i4.4033

embodied learning settings. Frontiers in Psychology, 8(AUG), 1-6.

https://doi.org/10.3389/fpsyg.201 7.01191

Smith, C. (2010). Choosing more mathematics: Happiness through work? Research in Mathematics Education, 12(2), 99-115. https://doi.org/10.1080/14794802. 2010.496972

Subanji. (2015). TEORI KESALAHAN KONSTRUKSI KONSEP DAN PEMECAHAN MASALAH MATEMATIKA. Universitas Negeri Malang.

Sweller, J., Ayres, P., \& Kalyuga, S. (2011). COGNITIVE LOAD THEORY (Vol. 82, Issue 1). Cambridge University Press. http://www.springer.com/series/8 640

Sweller, J., van Merriënboer, J. J. G., \& Paas, F. (2019). Cognitive Architecture and Instructional Design: 20 Years Later. Educational Psychology Review, 31(2), 261-292. https://doi.org/10.1007/s10648019-09465-5

Tachie, S. A. (2019). Meta-cognitive skills and strategies application: How this helps learners in mathematics problem-solving. Eurasia Journal of Mathematics, Science and Technology Education, 15(5). https://doi.org/10.29333/ejmste/10 5364

Voutsina, C., \& Ismail, Q. (2011). The use of additive composition in arithmetic: The case of children classified as low attainers. Research in Mathematics Education, 13(3), 287-303. https://doi.org/10.1080/14794802. 2011.624750
Yayuk, E., \& Husamah, H. (2020). The difficulties of prospective elementary school teachers in item problem solving for mathematics: Polya's steps. Journal for the Education of Gifted Young Scientists, 8(1), 361-378. https://doi.org/10.17478/jegys.665 833

Yohanes, B., Subanji, \& Sisworo. (2016). Students' Cognitive Load in Geometry Learning. Jurnal Pendidikan: Teori, Penelitian Dan Pengembangan, 1(2), 187195. 